\title{
FAKTOR IBU, JANIN DAN RIWAYAT PENYAKIT SEBAGAI RISIKO PREEKLAMPSIA DI ASIA DAN AFRIKA: SUATU META-ANALISIS
}

\section{Maternal, Fetal and History of Diseases Factors as Risk of Preeclampsia in Asia and Africa: a Meta-Analysis}

\author{
Miranda Ayunani*, Annisa Nurrachmawati, Rahmi Susanti \\ Fakultas Kesehatan Masyarakat, Universitas Mulawarman \\ *Email: ayunani.miranda@gmail.com
}

Naskah masuk 15 Oktober 2019; review 19 November 2019; disetujui terbit 30 Desember 2019

\begin{abstract}
Background: Preeclampsia accounts for nearly 10 percent of maternal deaths in Asia and Africa. Therefore, it is important to detect signs and symptoms early on by knowing the factors that are at risk for a mother experiencing preeclampsia.

Objective: To determine the risk factors for preeclampsia in Asia and Africa through the application of metaanalysis.

Method: A systematic review was carried out on 26 case-control and cohort studies related to risk factors for preeclampsia from four databases (PubMed, BioMed Central, ProQuest, and Google Scholar). The pooled odds ratio was calculated with the fixed-effect and random-effect model using Review Manager 5.3.

Result: A total of 20 studies consisting of 2,954,769 women were included in the meta-analysis. Risk factors for preeclampsia based on maternal factors were chronic hypertension=9.74(95\% CI 1.69-56.04), gestational diabetes $=9.28(95 \%$ CI 4, 49-19.19), pre-pregnancy body mass index=2.70(95\% CI 2.08-3.50), maternal age during pregnancy=2.37(95\% CI 2.29-2.46) and nulliparity=2.08(95\% CI 1.44-3.01). The fetal factor was multiple pregnancy=4.24(95\% CI 3.14-5.73). Four disease history factors were family history of preeclampsia $=13.99(95 \%$ CI 6.91-28.33), history of chronic hypertension $=8.28(95 \%$ CI 5.92-11.59), history of preeclampsia $=$ OR 6.90(95\% CI 3.58-13.31) and family history of hypertension=2.81(95\% CI 1.75-4.50).

Conclusion: The results of a meta-analysis of 10 risk factors for preeclampsia could be used as a screening tool to determine the magnitude of risk and early diagnosis of preeclampsia that allows timely intervention.
\end{abstract}

Key words: Maternal Factors, Chronic Hypertension, Preeclampsia, Meta-Analysis.

\begin{abstract}
Abstrak
Latar belakang: Preeklampsia menyumbang hampir 10 persen dari kematian ibu di Asia dan Afrika. Oleh karena itu, penting untuk menemukan tanda dan gejala sejak dini dengan mengetahui faktor-faktor yang berisiko untuk seorang ibu mengalami preeklampsia.

Tujuan: Mengetahui faktor risiko preeklampsia di Asia dan Afrika melalui penerapan meta-analisis.

Metode: Tinjauan sistematis dilakukan pada 26 studi kasus kontrol dan kohort terkait faktor risiko preeklampsia di empat database, yaitu PubMed, BioMed Central, ProQuest, dan Google Scholar. Pooled Odds Ratio dihitung dengan model fixed-effect dan random effect menggunakan Review Manager 5.3.

Hasil: Sebanyak 20 penelitian yang terdiri dari 2.954.769 wanita masuk dalam meta-analisis. Faktor risiko preeklampsia berdasarkan faktor ibu adalah hipertensi kronis=9,74(95\% CI 1,69-56,04), diabetes gestasional=9,28(95\% CI 4,49-19,19), indeks massa tubuh prakehamilan=2,70(95\% CI 2,08-3,50), usia ibu saat kehamilan=2,37(95\% CI 2,29-2,46) dan nuliparitas=2,08 (95\% CI 1,44-3,01). Faktor janin yaitu kehamilan multipel=4,24(95\% CI 3,14-5,73). Empat faktor riwayat penyakit yaitu riwayat keluarga preeklampsia $=13,99(95 \%$ CI $6,91-28,33)$, riwayat hipertensi kronis=8,28(95\% CI 5,92-11,59), riwayat preeklampsia $=(95 \%$ CI 3,58-13,31) dan riwayat keluarga hipertensi=2,81(95\% CI 1,75-4,50).

Kesimpulan: Hasil meta-analisis dari 10 faktor risiko preeklampsia dapat digunakan sebagai alat skrining untuk mengetahui besarnya risiko dan diagnosis dini preeklampsia, yang memungkinkan intervensi tepat waktu.
\end{abstract}

Kata kunci: Faktor Ibu, Hipertensi Kronis, Preeklampsia, Meta-analisis 


\section{PENDAHULUAN}

Preeklampsia dan gangguan hipertensi terkait kehamilan sebagai penyebab utama kematian ibu merenggut nyawa hampir $76.000 \mathrm{ibu}$ dan 500.000 bayi di seluruh dunia setiap tahun. ${ }^{1}$ Preeklampsia menyumbang hampir 10 persen dari kematian ibu di Afrika dan Asia. ${ }^{2}$ Studi follow-up Sensus Penduduk Indonesia 2010 menunjukkan preeklampsia menjadi salah satu penyebab kematian ibu di Indonesia. ${ }^{3}$ Preeklampsia memiliki dampak terbesar pada morbiditas dan mortalitas ibu dan bayi baru lahir. Menurut hasil analisis sekunder dari Survei Multinegara WHO, kasus near-miss pada ibu dengan preeklampsia delapan kali lebih sering terjadi dibandingkan dengan ibu tanpa preeklampsia. ${ }^{4}$ Peningkatan peluang kelahiran prematur pada ibu di Asia Tenggara dengan preeklampsia terjadi sebagai dampak pada bayi. ${ }^{5}$

Dampak preeklampsia dapat diminimalisir dengan menemukan tanda dan gejala sejak dini. Hal ini dapat dimulai dari mengetahui faktorfaktor yang berisiko untuk seorang ibu mengalami preeklampsia. Pengetahuan terkait faktor risiko preeklampsia dapat membantu tenaga kesehatan terkait dalam memantau pasien dan memperkirakan ibu hamil mana yang lebih mungkin mengembangkan preeklampsia.

Sejumlah besar penelitian termasuk studi metaanalisis telah dilakukan untuk mengevaluasi faktor-faktor risiko meliputi usia ibu saat kehamilan $^{6,7}$, indeks massa tubuh yang tinggi ${ }^{8-}$ ${ }^{12}$, diabetes gestasional ${ }^{6,13}$, nuliparitas ${ }^{14,15}$, kehamilan multipel ${ }^{6}$ dan riwayat penyakit seperti riwayat preeklampsia pada kehamilan sebelumnya $^{16}$, riwayat hipertensi kronis dan riwayat keluarga hipertens $1^{13,16}$ yang semuanya dianggap sebagai kontribusi.

Faktor-faktor tersebut sebagian besar merupakan faktor yang dapat dimodifikasi dan dilakukan pencegahan sejak dini sebelum kehamilan. Akan tetapi, banyaknya faktor risiko untuk preeklampsia yang telah diidentifikasi, sebagian besar dilakukan secara eksklusif di negara-negara barat. Situasi di negara-negara

\footnotetext{
* Corresponding author

(Email: ayunani.miranda@gmail.com)
}

pada wilayah Asia dan Afrika, terutama di negara-negara berpenghasilan rendah dan menengah, sebagian besar masih belum diketahui.

Meta-analisis memiliki peran dalam penelitian ilmiah. Hal ini ditunjukkan melalui penarikan kesimpulan yang lebih valid dan reliabel dengan "meningkatkan" besar sampel karena melakukan tinjauan beberapa studi dengan subjek yang sama. Tingkat signifikansi statistik yang dihasilkan dari studi meta-analisis juga lebih besar. Hal ini penting untuk meningkatkan validitas perbedaan yang diamati sehingga informasi yang dihasilkan pun lebih reliabel. ${ }^{17}$

Studi meta-analisis ini dilakukan untuk mengetahui faktor risiko preeklampsia di Asia dan Afrika. Kekuatan (power) statistik yang lebih besar dari hasil meta-analisis dapat membantu dalam melakukan ekstrapolasi ke populasi yang lebih besar sehingga kesimpulan yang diperoleh dapat dijadikan dasar dalam mengambil suatu kebijakan kesehatan masyarakat.

\section{METODE}

Upaya untuk melakukan penelitian terbaru terus dilakukan, tidak terkecuali penelitian metaanalisis yang dapat bermanfaat untuk mengetahui faktor risiko lainnya maupun mengoreksi faktor yang telah diketahui sebelumnya. Jenis penelitian adalah review atau sintesis yang bersifat kuantitatif dengan desain studi meta-analisis. Meta-analisis merupakan suatu teknik statistika untuk menggabungkan hasil dua atau lebih penelitian sejenis sehingga diperoleh paduan data secara kuantitatif. ${ }^{18}$

Melalui prosedur PRISMA, sampel penelitian adalah artikel terpublikasi terkait faktor risiko preeklampsia melalui database PubMed, BioMed Central, ProQuest, dan Google ScholarPubMed, BioMed Central, ProQuest, dan Google Scholar sejak tahun 2000-2018. Kriteria inklusi adalah studi kasus kontrol dan kohort. 
Kriteria eksklusi adalah studi yang tidak tersedia dalam bentuk full text dan bahasa selain bahasa Inggris.Sepuluh variabel (usia ibu saat kehamilan, indeks massa tubuh prakehamilan, diabetes gestasional, hipertensi kronis, nuliparitas, kehamilan multipel, riwayat preeklampsia, riwayat hipertensi kronis, riwayat keluarga hipertensi dan riwayat keluarga preeklampsia) sebagai variabel independen (bebas); dan preeklampsia sebagai variabel dependen (terikat).

Pencarian dilakukan dengan memasukkan kata kunci sebagai berikut: "(Advanced maternal age OR body mass index pre-pregnancy $O R$ gestational diabetes OR chronic hypertension OR nulliparity OR multiple pregnancy OR family history of hypertension OR history of preeclampsia OR history of chronic hypertension OR family history of preeclampsia) AND preeclampsia AND (Asia OR Africa)".

Artikel yang memiliki judul dan abstrak yang berpotensi relevan dilakukan tinjauan pada tahap berikutnya secara lengkap (full text), sedangkan artikel yang tidak relevan dieksklusi. Selanjutnya, artikel yang terpilih berdasarkan tinjauan full text dimasukkan dalam systematic review dan ditinjau lebih lanjut terkait kelengkapan data, kejelasan definisi faktor risiko dan hal lainnya sebagai syarat dimasukkan dalam meta-analisis (Gambar 1).

Analisis data dilakukan untuk mendapatkan nilai pooled odds ratio yang merupakan nilai odds ratio gabungan dari penelitian menggunakan fixed effect model dengan metode Mantel Haenszel dan random effect model dengan metode DerSimonian Laird. Data dianalisis dengan menggunakan software Review Manager 5.3. Uji heterogenitas dilakukan dengan tujuan untuk menentukan model penggabungan pada meta-analisis. Uji statistik $\mathrm{I}^{2}$ dilakukan untuk menilai heterogenitas di antara sejumlah effect size studi dinyatakan dalam bentuk persentase. Uji Cochran $\mathrm{Q}$ juga digunakan untuk menilai heterogenitas dengan nilai p. Hasil akhir metaanalisis berupa forest plot dengan nilai OR gabungan (pooled odds ratio) dan terdapat effect size pada masing-masing studi. Hasil funnel plot juga dianalisis untuk penilaian bias publikasi pada hasil akhir meta-analisis. Nilai akhir yang digunakan sebagai jawaban dari tujuan penelitian adalah nilai pooled odds ratio yang menunjukkan nilai ORgabungan dari beberapa studi. Hal ini yang menunjukkan seberapa besar faktor risiko dari masing-masing variabel yang diteliti.

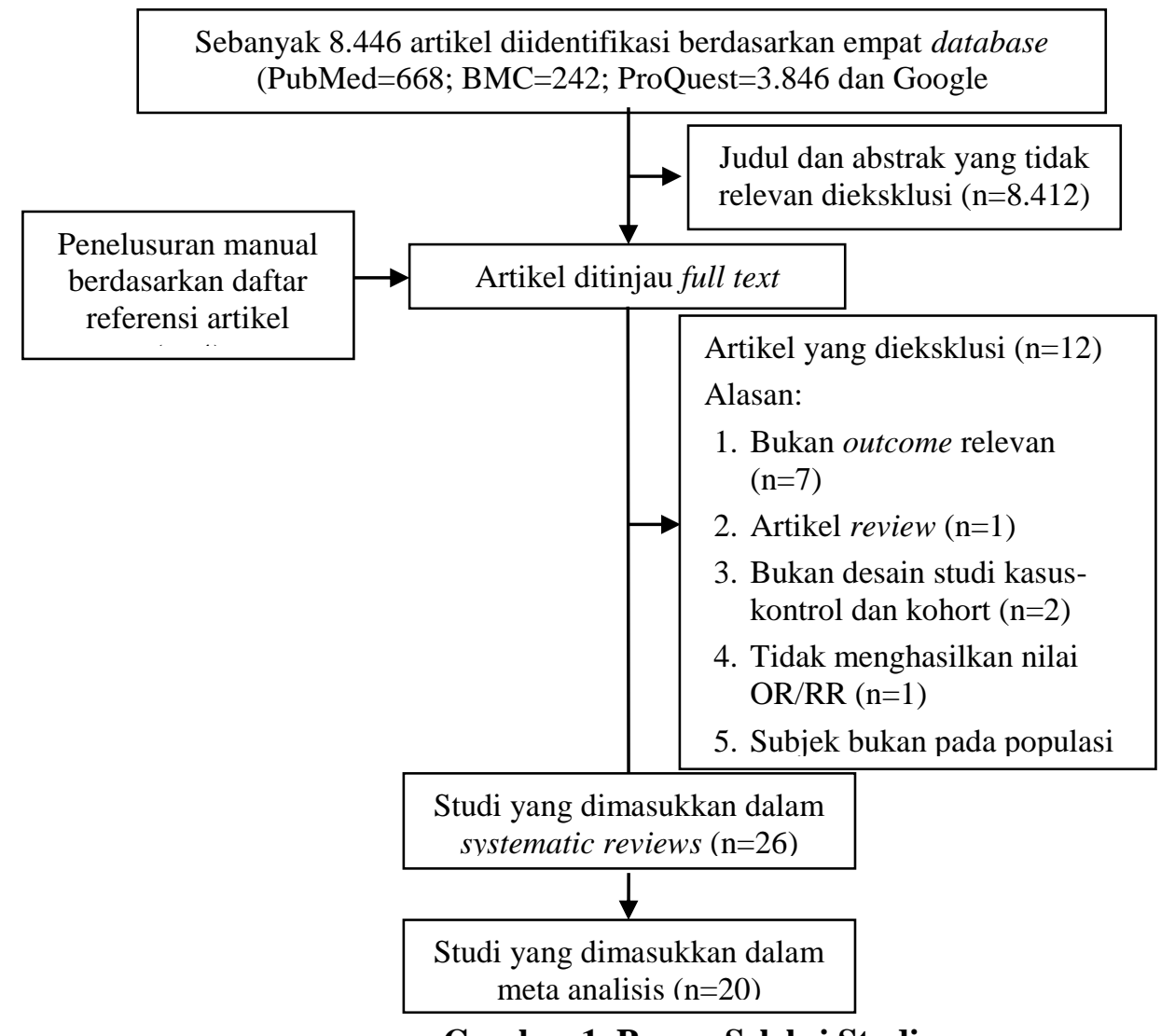

Gambar 1. Proses Seleksi Studi

Jurnal Kesehatan Reproduksi, 10(2), 2019 
Setelah mendapatkan hasil meta-analisis dari 10 variabel yang didapatkan, penulis memasukkan hasil dengan meta-analisis yang terbaik dibandingkan variabel lainnya berdasarkan jumlah studi dan nilai OR dari masing-masing studi yang digabungkan dengan interval kepercayaan yang sesuai.

\section{HASIL}

Terdapat 20 penelitian (14 kasus kontrol dan 6 kohort) yang masuk dalam meta-analisis, masing-masing 10 penelitian dari Asia dan Afrika (tabel 1) dengan jumlah 10 variabel. Risiko terjadinya preeklampsia di Asia dan Afrika berdasarkan faktor ibu adalah hipertensi kronis, diabetes gestasional, indeks massa tubuh prakehamilan, usia ibu saat kehamilan, dan nuliparitas.

Tabel 1. Tinjauan Sistematis Faktor Risiko Preeklampsia di Asia dan Afrika

\begin{tabular}{|c|c|c|c|c|c|}
\hline \multirow{2}{*}{ Peneliti, Tahun } & \multirow{2}{*}{ Negara } & \multirow{2}{*}{ Desain Studi } & \multirow{2}{*}{ Faktor Risiko } & \multicolumn{2}{|c|}{ Jumlah Sampel } \\
\hline & & & & Kasus & Kontrol \\
\hline $\begin{array}{l}\text { Shamsi et al., } \\
2010\end{array}$ & Pakistan & Kasus kontrol & $\begin{array}{l}\text { Riwayat keluarga hipertensi, } \\
\text { Diabetes gestasional }\end{array}$ & 131 & 262 \\
\hline $\begin{array}{l}\text { Luealon \& } \\
\text { Phupong, } 2010\end{array}$ & Thailand & Kasus kontrol & $\begin{array}{l}\text { Usia ibu ( } \geq 35 \text { tahun), Nuliparitas, } \\
\text { IMT prakehamilan }\left(\geq 30 \mathrm{~kg} / \mathrm{m}^{2}\right) \text {, } \\
\text { Kehamilan multipel, Riwayat } \\
\text { preeklampsia, Riwayat hipertensi } \\
\text { kronis }\end{array}$ & 309 & 309 \\
\hline $\begin{array}{l}\text { Khader et al., } \\
2007\end{array}$ & Yordania & Kasus kontrol & $\begin{array}{l}\text { Usia ibu, Riwayat preeklampsia, } \\
\text { Kelahiran kembar, IMT } \\
\text { prakehamilan }\end{array}$ & 230 & 115 \\
\hline $\begin{array}{l}\text { Kumar et al., } \\
2010\end{array}$ & India & Kasus kontrol & $\begin{array}{l}\text { IMT prakehamilan, Kehamilan } \\
\text { multipel, Riwayat hipertensi kronis, } \\
\text { Riwayat keluarga hipertensi }\end{array}$ & 100 & 100 \\
\hline Fang et al., 2009 & Thailand & Kasus kontrol & IMT prakehamilan $>30 \mathrm{~kg} / \mathrm{m}^{2}$ & 150 & 150 \\
\hline $\begin{array}{l}\text { Al-Tairi et al., } \\
2017\end{array}$ & Yaman & Kasus kontrol & $\begin{array}{l}\text { Hipertensi kronik, Riwayat } \\
\text { keluarga preeklampsia }\end{array}$ & 103 & 103 \\
\hline Grum et al., 2017 & Ethiopia & Kasus kontrol & $\begin{array}{l}\text { Riwayat preeklampsia, Kehamilan } \\
\text { multipel }\end{array}$ & 97 & 194 \\
\hline $\begin{array}{l}\text { Anorlu et al., } \\
2005\end{array}$ & Nigeria & Kasus kontrol & $\begin{array}{l}\text { Nuliparitas, Riwayat preeklampsia, } \\
\text { Riwayat hipertensi kronis, } \\
\text { Kehamilan multipel }\end{array}$ & 128 & 240 \\
\hline $\begin{array}{l}\text { Kiondo et al., } \\
2012\end{array}$ & Uganda & Kasus kontrol & $\begin{array}{l}\text { Riwayat hipertensi kronis, Riwayat } \\
\text { keluarga hipertensi }\end{array}$ & 207 & 352 \\
\hline Grum et al., 2018 & Ethiopia & Kasus kontrol & Nuliparitas & 81 & 162 \\
\hline $\begin{array}{l}\text { Mohammed et } \\
\text { al., } 2017\end{array}$ & Ethiopia & Kasus kontrol & $\begin{array}{l}\text { Riwayat preeklampsia, Riwayat } \\
\text { keluarga hipertensi }\end{array}$ & 87 & 174 \\
\hline $\begin{array}{l}\text { Wandabwa et al., } \\
2010\end{array}$ & Uganda & Kasus kontrol & $\begin{array}{l}\text { Hipertensi kronis, Riwayat keluarga } \\
\text { hipertensi, Nuliparitas }\end{array}$ & 143 & 500 \\
\hline $\begin{array}{l}\text { Endeshaw et al., } \\
2016\end{array}$ & Ethiopia & Kasus kontrol & $\begin{array}{l}\text { Usia ibu, Kehamilan multipel, } \\
\text { Riwayat keluarga hipertensi }\end{array}$ & 151 & 302 \\
\hline $\begin{array}{l}\text { Guerrier et al., } \\
2013\end{array}$ & Nigeria & Kasus kontrol & $\begin{array}{l}\text { Riwayat preeklampsia, Riwayat } \\
\text { hipertensi }\end{array}$ & 419 & 1257 \\
\hline Shao et al., 2017 & China & Kohort & Overweight/ obesitas & 347 & 9863 \\
\hline You et al., 2018 & Taiwan & Kohort & Usia ibu & 32742 & 2884347 \\
\hline Lee et al., 2000 & Taiwan & Kohort & $\begin{array}{l}\text { Riwayat preeklampsia, Kehamilan } \\
\text { multipel, IMT prakehamilan, Usia } \\
\text { ibu >34 tahun, Nulliparitas }\end{array}$ & 415 & 29735 \\
\hline Li et al., 2015 & China & Kohort & $\begin{array}{l}\text { Usia ibu, IMT prakehamilan }>24 \\
\mathrm{~kg} / \mathrm{m}^{2} \text {, Diabetes gestasional }\end{array}$ & 111 & 6223 \\
\hline $\begin{array}{l}\text { Mrema et al., } \\
2018\end{array}$ & Tanzania & Kohort & $\begin{array}{l}\text { Indeks massa tubuh prakehamilan, } \\
\text { usia ibu }\end{array}$ & 17738 & 5082 \\
\hline Musa et al., 2018 & Nigeria & Kohort & $\begin{array}{l}\text { Riwayat preeklampsia, IMT } \\
\text { prakehamilan }\end{array}$ & 27 & 307 \\
\hline
\end{tabular}


Variasi antarpenelitian yang heterogen ditunjukkan pada uji heterogenitas dengan nilai $p=0,0002 \quad(p<0,05)$ dan $I^{2}=88 \%$. Terdapat hubungan yang signifikan dengan nilai $p$ sebesar $0,01(\mathrm{p}<0,05)$. Nilai pooled odds ratio sebesar 9,74 (95\% CI 1,69-56,04) dihasilkan melalui random-effect model. Hal ini dapat diinterpretasikan bahwa seorang ibu dengan hipertensi kronis memiliki risiko 9,74 kali lebih besar untuk mengalami preeklampsia.

Uji heterogenitas menunjukkan nilai $\mathrm{p}$ lebih besar dari 0,05 , yaitu $\mathrm{p}=0,21$ dengan $\mathrm{I}^{2}=35$ persen yang artinya variasi antarpenelitian adalah homogen. Diabetes gestasional dengan preeklampsia menunjukkan hubungan yang signifikan dengan nilai $\mathrm{p}$ sebesar 0,00001 $(\mathrm{p}<0,05)$. Fixed-effect model menghasilkan nilai pooled odds ratio sebesar 9,28 (95\% CI 4,4919,19). Hal ini menunjukkan bahwa seorang ibu yang pada kehamilannya mengalami diabetes memiliki risiko 9,28 kali lebih besar untuk mengalami preeklampsia.

Nilai $\mathrm{p}$ yang diperoleh dari uji heterogenitas lebih kecil dari 0,05 , yaitu 0,0002 dengan $\mathrm{I}^{2}=72$ persen, yang menunjukkan variasi antarpenelitian adalah heterogen. Nilai $p$ menunjukkan bahwa terdapat hubungan yang signifikan antara indeks massa tubuh prakehamilan dengan preeklampsia dengan nilai $\mathrm{p}=0,00001(\mathrm{p}<0,05)$. Random-effect model menghasilkan nilai pooled odds ratio sebesar 2,7 (95\% CI 2,08-3,5). Hal ini dapat disimpulkan bahwa seorang ibu yang pada saat sebelum hamil memiliki indeks massa tubuh $>24 \mathrm{~kg} / \mathrm{m}^{2}$ dan $>30 \mathrm{~kg} / \mathrm{m}^{2}$ yang dikategorikan sebagai kelebihan berat badan dan obesitas memiliki risiko 2,7 kali lebih besar untuk mengalami preeklampsia.

Terdapat sepuluh penelitian yang meneliti terkait indeks massa tubuh prakehamilan dengan preeklampsia, yang mana merupakan jumlah penelitian terbanyak dari variabel lainnya yang masuk dalam meta-analisis. Penelitian oleh Mrema, et al memiliki nilai OR terkecil, yaitu 1,6, namun dengan jumlah kasus dan kontrol terbesar, sedangkan pada penelitian Kumar, et $\mathrm{al}^{37}$ dengan jumlah kasus kontrol terkecil memiliki OR sebesar 4,83 (Gambar 2).

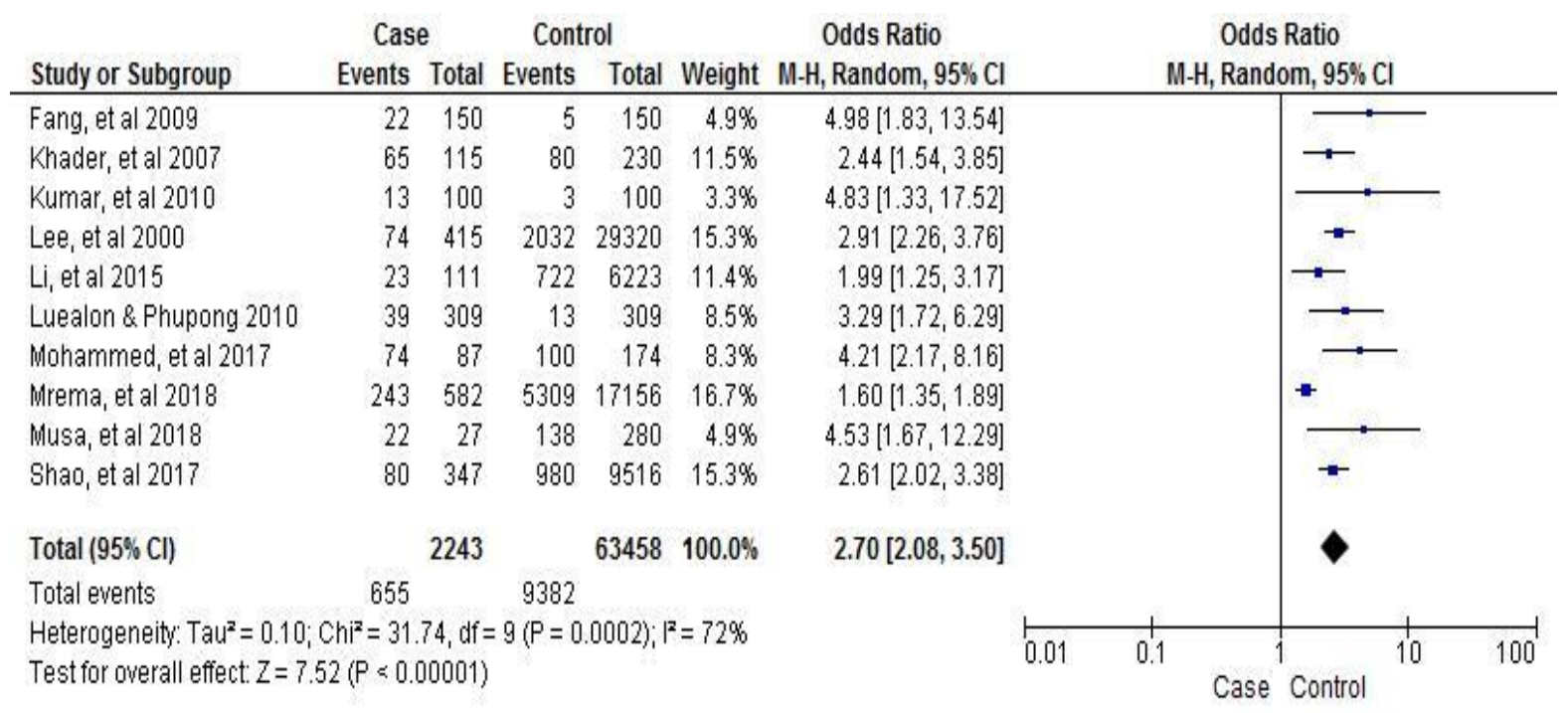

\section{Gambar 2. Forest Plot Indeks Massa Tubuh Prakehamilan dengan Preeklampsia di Asia dan Afrika}




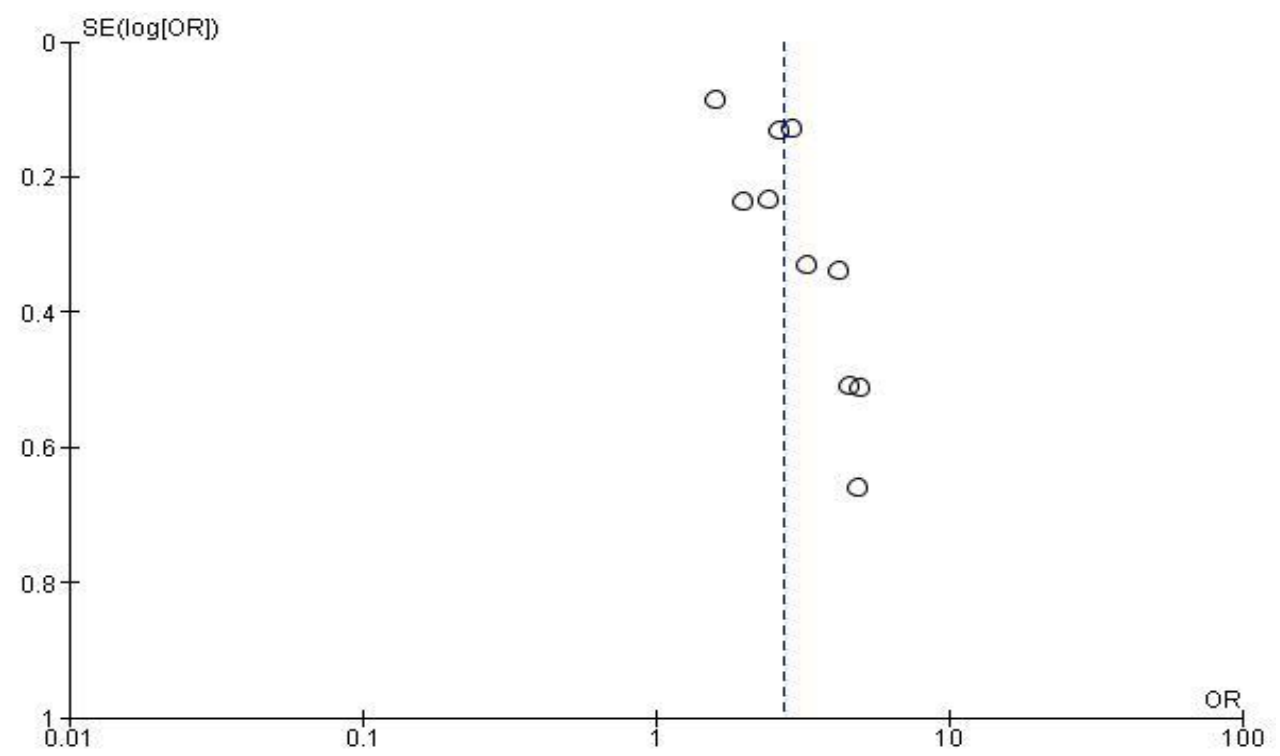

\section{Gambar 3. Funnel Plot Indeks Massa Tubuh Prakehamilan dengan Preeklampsia di Asia dan Afrika}

Sepuluh penelitian masuk dalam meta-analisis pada variabel ini, tiga di antaranya berasal dari Afrika. Variasi penelitian menunjukkan heterogenitas yang sedang dengan $\mathrm{I}^{2}=72$ persen (Gambar 3). Hal ini disebabkan karena cut off point IMT pada masing-masing negara memiliki variasi yang cukup beragam. Penelitian di Asia cenderung menggunakan cut off point yang lebih rendah dalam menentukan kategori obesitas, sedangkan penelitian di Afrika menggunakan standar WHO yang mengategorikan obesitas dengan IMT $\geq 30$ $\mathrm{kg} / \mathrm{m}^{2}$.

Variabel indeks massa tubuh prakehamilan menggabungkan cut off point dengan kategori kelebihan berat badan (overweight) dan obesitas menjadi satu analisis. Hal ini didasarkan karena penelitian-penelitian terdahulu telah banyak menemukan bahwa risiko preeklampsia sudah muncul ketika IMT ibu berada pada kategori overweight. Selain itu, beberapa negara Asia, salah satunya China, menggunakan cut off point tersendiri. Hal ini bertujuan agar tidak mengabaikan dampak risiko preeklampsia yang sudah dimulai bahkan sebelum ibu masuk dalam kategori obesitas sesuai standar WHO.

Perbedaan karakteristik sampel juga menjadi penyebab terjadinya heterogenitas penelitian. Variabel ini cenderung didominasi oleh penelitian di Asia terutama negara China yang merupakan negara dengan perekonomian menengah ke atas, sementara penelitian di Afrika yang berasal dari negara Ethiopia, Tanzania dan Nigeria termasuk dalam negara berpenghasilan menengah ke bawah. Akan tetapi, sepuluh penelitian memiliki nilai OR yang tidak jauh berbeda, yang menunjukkan bahwa hasil cukup konsisten ketika studi dilakukan pada wilayah dan populasi yang berbeda.

Variasi antar penelitian adalah homogen, hal ini dapat dillihat dari nilai $\mathrm{p}$ pada uji heterogenitas adalah 0,26, lebih besar dari pada 0,05. Terdapat hubungan yang signifikan antara ibuusia ibu saat kehamilan dengan preeklampsia, hal ini dibuktikan oleh nilai $\mathrm{p}<0,05$ yaitu $\mathrm{p}=0,00001$. Fixed-effect model menghasilkan nilai pooled odds ratio sebesar 2,37 (95\% CI 2,29-2,46), sehingga dapat ditarik kesimpulan bahwa seorang ibu yang berusia lebih dari 35 tahun saat hamil memiliki risiko 2,37 kali lebih besar untuk mengalami preeklampsia pada kelompok kasus dibandingkan kelompok kontrol.

Uji heterogenitas dengan nilai $\mathrm{p}=0,0002$ dan $\mathrm{I}^{2}=82 \%$ menunjukkan bahwa variasi antarpenelitian adalah heterogen. Nilai $p$ sebesar 0,0001 menunjukkan bahwa terdapat hubungan yang signifikan antara nuliparitas dengan preeklampsia $(\mathrm{p}<0,05)$. Sebesar 2,08 (95\% CI 1,44-3,01) sebagai nilai pooled odds ratio dihasilkan melalui random-effect model. Hal ini diartikan bahwa seorang ibu yang sebelumnya belum pernah melahirkan atau merupakan kehamilan pertamanya memiliki risiko 2,08 kali lebih besar untuk mengalami preeklampsia. 
Terdapat satu faktor janin, yaitu kehamilan multipel sebagai faktor risiko preeklampsia di Asia dan Afrika. Variasi antarpenelitian adalah homogen, hal ini dapat dillihat dari nilai p pada uji heterogenitas adalah 0,29, lebih besar dari pada 0,05 , dan $\mathrm{I}^{2}=18$ persen. Terdapat hubungan yang signifikan antara kehamilan multipel dengan preeklampsia, hal ini dibuktikan oleh nilai $\mathrm{p}<0,05$ yaitu $\mathrm{p}=0,00001$. Fixed-effect model menghasilkan nilai pooled odds ratio sebesar 3,97 (95\% CI 2,99-5,29), sehingga dapat ditarik kesimpulan bahwa seorang ibu yang hamil dengan dua atau lebih janin yang dikandung memiliki risiko 3,97 kali lebih besar untuk mengalami preeklampsia pada kelompok kasus dibandingkan kelompok kontrol.

Selanjutnya adalah faktor riwayat penyakit, yaitu riwayat keluarga preeklampsia, riwayat hipertensi kronis, riwayat preeklampsia dan riwayat keluarga hipertensi. Hasil meta-analisis menunjukkan uji heterogenitas dengan nilai $\mathrm{p}=0,23$ dan $\mathrm{I}^{2}=30$ persen menunjukkan bahwa variasi antarpenelitian adalah homogen. Nilai $\mathrm{p}$ sebesar 0,00001 menunjukkan bahwa terdapat hubungan yang signifikan antara riwayat keluarga preeklampsia dengan preeklampsia ( $\mathrm{p}<0,05)$. Sebesar 13,99 (95\% CI 6,91-28,33) sebagai nilai pooled odds ratio dihasilkan melalui fixed-effect model. Hal ini diartikan bahwa seorang ibu dengan anggota keluarga yang memiliki riwayat preeklampsia berisiko 13,99 kali lebih besar untuk mengalami preeklampsia.

Uji heterogenitas menunjukkan nilai $\mathrm{p}$ lebih besar dari 0,05 , yaitu $\mathrm{p}=0,22$ yang artinya variasi antarpenelitian adalah homogen. Riwayat hipertensi kronis dengan preeklampsia menunjukkan hubungan yang signifikan dengan nilai $\mathrm{p}$ sebesar $0,00001(\mathrm{p}<0,05)$. Fixed-effect model menghasilkan nilai pooled odds ratio sebesar 8,28 (95\% CI 5,92-11,59). Hal ini menunjukkan bahwa seorang ibu dengan riwayat hipertensi kronis memiliki risiko 8,28 kali lebih besar untuk mengalami preeklampsia.

Riwayat preeklampsia sebelumnya menjadi faktor risiko terjadinya preeklampsia kembali pada ibu di Asia dan Afrika. Pada uji heterogenitas dapat dilihat nilai $\mathrm{p}$ lebih kecil dari 0,05 , yaitu 0,00001 dengan $\mathrm{I}^{2}=86$ persen, yang menunjukkan variasi antarpenelitian adalah heterogen. Nilai $p$ menunjukkan bahwa terdapat hubungan yang signifikan antara riwayat preeklampsia dengan preeklampsia dengan nilai $\mathrm{p}=0,00001 \quad(\mathrm{p}<0,05)$. Randomeffect model menghasilkan nilai pooled odds ratio sebesar 6,9 (95\% CI 3,58-13,31). Hal ini dapat disimpulkan bahwa seorang ibu dengan preeklampsia pada kehamilan sebelumnya memiliki risiko 6,9 kali lebih besar untuk mengalami preeklampsia.

Variasi antarpenelitian yang heterogen ditunjukkan pada uji heterogenitas dengan nilai $\mathrm{p}=0,0002(\mathrm{p}<0,05)$ dan $\mathrm{I}^{2}=79$ persen. Terdapat hubungan yang signifikan dengan nilai $p$ sebesar $0,0001 \quad(\mathrm{p}<0,05)$. Nilai pooled odds ratio sebesar $2,81 \quad(95 \%$ CI $\quad 1,75-4,50)$ dihasilkan melalui random-effect model. Hal ini dapat diinterpretasikan bahwa seorang ibu dengan riwayat keluarga hipertensi memiliki risiko 2,81 kali lebih besar untuk mengalami preeklampsia.

\section{PEMBAHASAN}

Hasil yang menunjukkan hipertensi kronis sebagai faktor risiko terbesar preeklampsia di Asia dan Afrika sejalan dengan hasil systematic review yang menyatakan bahwa hipertensi kronis berhubungan dengan banyak hasil yang buruk (adverse outcome), termasuk salah satunya adalah superimposed pre-eclampsia. ${ }^{19}$ Penelitian systematic review pada studi kohort di Asia juga mendukung hasil meta-analisis yang menunjukkan bahwa hipertensi kronis menjadi salah satu faktor risiko dengan odds ratio tertinggi, yakni sebesar $7,174 .^{20}$

Mengedukasi wanita usia reproduksi mengenai pentingnya mengontrol tekanan darah baik sebelum, selama dan sesudah kehamilan adalah hal yang penting. Melakukan penilaian sebelum kehamilan untuk menghindari penyebab sekunder hipertensi, mengevaluasi tekanan darah untuk memastikan berada dalam kondisi optimal, membahas peningkatan risiko preeklampsia, dan memberikan edukasi mengenai perubahan obat apa pun sebelum kehamilan dapat dilakukan. Wanita dengan hipertensi kronis juga harus dianjurkan untuk mempertahankan asupan natrium yang rendah, baik dengan mengurangi atau mengganti garam natrium sebelum kehamilan. ${ }^{21}$

Hasil penelitian menyatakan, diabetes gestasional menjadi faktor risiko terbesar kedua terjadinya preeklampsia di Asia. Sebuah penelitian review terkait hubungan preeklampsia dan diabetes mengonfirmasi hasil yang serupa. ${ }^{22}$ Diabetes gestasional menjadi faktor risiko independen untuk preeklampsia. 
Hal ini dibuktikan oleh penelitian retrospektif dari 647.392 kehamilan yang menemukan bahwa peluang preeklampsia meningkat di antara wanita dengan diabetes gestasional (aOR:1,29, 95\%CI: 1,19-1,41), bahkan setelah mengendalikan usia, kebangsaan, status pekerjaan, merokok, paritas, kehamilan multifetal, status berat badan prakehamilan dan kenaikan berat badan kehamilan. ${ }^{23}$

Intervensi untuk penanganan diabetes gestasional juga dapat mengurangi risiko preeklampsia. Sebuah uji coba kontrol acak (dengan treatment konseling gizi, terapi diet, dan insulin jika diperlukan) vs tanpa treatment di antara hampir 1.000 wanita dengan diabetes gestasional ringan menemukan bahwa treatment dikaitkan dengan 55 persen risiko preeklampsia yang berkurang (RR: 0,46; 95\%CI: 0,22$0,97){ }^{24}$ Tinjauan sistematis dan meta-analisis pada uji coba acak juga menemukan bahwa manajemen diabetes gestasional yang tepat (terapi nutrisi, pemantauan glukosa darah sendiri, pemberian insulin jika target konsentrasi glukosa darah tidak hanya dipenuhi dengan diet) mengakibatkan pengurangan risiko preeklampsia (risiko relatif [RR] 0,62; 95\% CI 0,43-0,89; 72/1001 [7,2\%] dibandingkan $119 / 1013[11,7 \%]$, dengan tiga studi uji coba). ${ }^{25}$

Indeks massa tubuh prakehamilan menjadi faktor risiko preeklampsia di Asia dan Afrika pada penelitian ini. Beberapa penelitian systematic review dan meta-analisis sebelumnya juga menunjukkan hal yang sama dan konsisten. ${ }^{10,12,14,16}$ Indeks massa tubuh ibu adalah salah satu faktor risiko preeklampsia yang paling banyak dibahas dan bisa menjadi masalah kompleks di antara negara-negara Asia maupun Afrika. Sebesar 35 persen orang dewasa saat ini dianggap kelebihan berat badan atau obesitas dan wanita sendiri lebih cenderung kelebihan berat badan dan obesitas daripada pria. Hal ini memiliki efek yang luas pada kesehatan reproduksi dan khususnya kehamilan, dengan wanita gemuk menghadapi peningkatan risiko preeklampsia. ${ }^{26}$

Variabel IMT merupakan variabel yang paling mudah dimodifikasi, namun juga memiliki berbagai faktor lainnya yang mempengaruhi. Langkah awal yang dapat dilakukan untuk pencegahan adalah memberikan pendidikan kesehatan prakehamilan. Perlu diperhatikan bahwa wanita yang kelebihan berat badan dan obesitas pada usia reproduksi harus didorong untuk mempraktikkan gaya hidup sehat, termasuk pengurangan berat badan sebelum kehamilan. Berat badan yang sehat sebelum kehamilan dapat menurunkan risiko gangguan hipertensi terkait kehamilan, termasuk preeklampsia. $^{21}$

Hasil dari penelitian ini juga menunjukkan usia ibu $\geq 35$ tahun saat kehamilan merupakan faktor risiko preeklampsia di Asia dan Afrika yang mana konsisten dengan penelitian lainnya. ${ }^{6,7,14}$ Risiko relatif preeklampsia semakin meningkat dengan bertambahnya usia ibu. Pada kelompok umur 35-39 tahun memiliki risiko sebesar 2,99 kali lipat ( $\mathrm{p}<0,001)$ dan 40 tahun sebesar 5,13 kali lipat $(p<0,001) .{ }^{27}$ Memberikan informasi kepada wanita usia subur (WUS) tentang risiko obstetrik pada kehamilan usia ibu $\geq 35$ tahun dapat membantu membuat keputusan berdasarkan informasi yang didapat.

Faktor ibu yang terakhir adalah nuliparitas. Hasil penelitian menyatakan wanita nulipara memiliki risiko preeklampsia yang mana sejalan dengan bukti dari studi meta-analisis oleh Bartsch et al. ${ }^{16}$ Risiko preeklampsia meningkat 2,91 kali pada ibu dengan nuliparitas berdasarkan hasil systematic review studi kohort terkontrol yang dilakukan sebelumnya. ${ }^{14}$ Hasil dari analisis sekunder dari Survei Global World Health Organization (WHO) tentang kesehatan ibu dan perinatal multinegara menyebutkan bahwa nuliparitas (AOR: 2,04; 95\% CI 1,92-2,16) ditemukan sebagai faktor risiko yang signifikan. ${ }^{28}$

Faktor lainnya yang mempengaruhi terjadinya preeklampsia adalah janin. Preeklampsia lebih sering terjadi pada wanita yang kemungkinan memiliki plasenta besar, seperti wanita dengan kehamilan multipel. Sebuah studi kasus kontrol di Tanzania menunjukkan bahwa dibandingkan dengan kehamilan tunggal, wanita dengan kehamilan multipel memiliki peningkatan risiko preeklampsia $(\mathrm{OR}=2,6 \quad 95 \%$ CI $1,7-3,9) .{ }^{29}$ Sebuah systematic review juga menunjukkan bahwa ibu dengan kehamilan kembar memiliki risiko mengalami preeklampsia sebesar 2,93 kali. ${ }^{14}$ Tenaga kesehatan butuh untuk memberi konseling pada wanita dengan kehamilan multipel selama pelayanan antenatal mengenai risiko potensial yang mungkin terjadi. Tindak lanjut dan intervensi tepat waktu juga dapat membantu mencegah outcome yang buruk terkait dengan kehamilan multipel.

Faktor riwayat penyakit juga memberikan kontribusi risiko terhadap kejadian 
preeklampsia di Asia dan Afrika. Khusus di wilayah Asia, riwayat keluarga preeklampsia menjadi faktor risiko terbesar karena memiliki nilai pooled $O R$ terbesar. Sebuah hasil systematic review mendukung hasil metaanalisis ini dengan menunjukkan bahwa risiko preeklampsia meningkat pada wanita dengan riwayat keluarga yang juga mengalami preeklampsia $(2,90 ; 1,70-4,93) .^{14}$

Seorang ibu dengan riwayat hipertensi kronis juga memiliki risiko mengalami preeklampsia di kehamilannya, yang mana sesuai dengan penelitian oleh Conde-agudelo \& Belizan ${ }^{30}$ yang menyatakan bahwa riwayat hipertensi kronis merupakan salah satu faktor yang secara independen terkait dengan peningkatan risiko preeklampsia. Temuan oleh Direkvandmoghadam, Khosravi, \& Sayehmiri ${ }^{31}$ menunjukkan ada beberapa faktor risiko untuk preeklampsia, salah satunya adalah riwayat hipertensi dengan OR sebesar 2,34.

Penelitian ini juga menunjukkan bahwa memiliki riwayat preeklampsia merupakan faktor risiko penting untuk terulangnya kejadian preeklampsia. Hal ini didukung oleh studi metaanalisis lainnya dengan pooled relative risk sebesar $8,4 \quad(95 \%$ CI $\quad 7,1-9,9) .{ }^{16}$ Riwayat preeklampsia juga merupakan faktor risiko terbesar di Asia menurut hasil systematic review yang dilakukan pada perempuan Asia dengan OR sebesar 8,85. ${ }^{20}$ Systematic review dari studi kohort yang terkontrol menunjukkan bahwa risiko preeklampsia meningkat pada wanita dengan riwayat preeklampsia sebelumnya (RR:7,19, 95\% CI 5,85-8,83). ${ }^{14}$ Studi prospesktif terdahulu juga menunjukkan bahwa dari lima ratus wanita dengan riwayat preeklampsia sebelumnya yang membutuhkan persalinan pada usia kehamilan 37 minggu, 117 wanita $(23 \%)$ mengalami preeklampsia kembali. Penelitian ini juga mengidentifikasi faktor prediktif untuk terjadinya preeklampsia kembali yang salah satunya adalah merupakan orang Asia (OR, 2,98; 95\% CI, 1,33-6,59). ${ }^{32}$

Riwayat keluarga hipertensi merupakan faktor risiko preeklampsia yang terakhir berdasarkan faktor riwayat penyakit. Studi di Euthopia mengonfirmasi hasil ini yang menunjukkan risiko preeklampsia pada ibu dengan riwayat keluarga yang mengalamai hipertensi. Wanita dengan riwayat keluarga hipertensi memiliki peluang tujuh kali lebih besar untuk mengalami preeklampsia dibandingkan dengan mereka yang tidak memiliki riwayat. ${ }^{33}$
Studi meta-analisis memberikan hasil yang lebih kuat dibandingkan dengan jenis tinjauan pustaka lainnya karena melibatkan analisis statistik dalam menarik kesimpulan dengan metode yang sistematis. Studi ini juga melibatkan jumlah sampel yang besar sehingga interpretasi data dapat dilakukakan dengan tingkat kepercayaan yang lebih besar. Hasil meta-analisis terkait faktor risiko preeklampsia di antara orang Asia dan Afrika dapat digunakan untuk meningkatkan kualitas skrining preeklampsia melalui penilaian risiko pada saat pelayanan antenatal sehingga surveilans rutin yang sesuai untuk mendeteksi preeklampsia dapat direncanakan untuk sisa kehamilan.

Penelitian ini memiliki keterbatasan, antara lain: 1) Beberapa variabel memiliki nilai pooled OR dengan interval kepercayaan yang luas dari studi yang dimasukkan dalam meta-analisis; 2) Terdapat dua variabel dengan hanya dua penelitian yang masuk dalam meta-analisis, yaitu diabetes gestasional dan riwayat keluarga preeklampsia; 3) Studi yang dimasukkan dalam meta-analisis adalah studi observasional yang secara keseluruhan belum bisa menjawab hubungan sebab-akibat antara faktor-faktor risiko terkait dengan kejadian preeklampsia; 4) Penelitian ini hanya meneliti sepuluh variabel yang dikategorikan dalam tiga faktor, yaitu ibu, janin dan riwayat penyakit. Masih terdapat variabel lainnya yang turut mempengaruhi tingkat risiko kejadian preeklampsia, seperti akses ke pelayanan antenatal dan lainnya; 5) Sumber database yang digunakan cukup terbatas sehingga terdapat kemungkinan studi yang masuk dalam kriteria untuk dianalisis, namun tidak teridentifikasi.

\section{KESIMPULAN}

Meta-analisis ini mengonfirmasi faktor ibu (hipertensi kronis, diabetes gestasional, indeks massa tubuh prakehamilan, usia ibu saat kehamilan dan nuliparitas), faktor janin (kehamilan multipel), serta faktor riwayat penyakit (riwayat keluarga preeklampsia, riwayat hipertensi kronis, riwayat preeklampsia, dan riwayat keluarga hipertensi) sebagai faktor risiko preeklampsia di Asia dan Afrika.

\section{SARAN}

Bagi petugas kesehatan, variabel dapat digunakan sebagai alat skrining untuk mengetahui besarnya risiko preeklampsia pada 
ibu dan diagnosis dini dengan cara mengembangkan daftar praktis (seperti check list) berdasarkan faktor risiko terkait dengan preeklampsia di Asia dan Afrika. Terdapat faktor risiko yang dapat dimodifikasi, seperti hipertensi kronis dan IMT prakehamilan. Petugas kesehatan dan ibu dapat fokus dalam melakukan perubahan perilaku kesehatan, seperti sebelum merencanakan kehamilan dapat dilakukan penurunan berat badan yang ideal dengan pengaturan pola gizi seimbang. Bagi peneliti, meta-analisis penting untuk dilakukan sebagai salah satu bentuk pemanfaatan data yang ada, dalam hal ini adalah artikel-artikel terpublikasi, baik pada variabel ini maupun pada variabel dan topik lainnya.

\section{UCAPAN TERIMA KASIH}

Penulis mengucapkan terima kasih kepada peneliti-peneliti yang telah berkontribusi menyediakan data dalam penelitiannya untuk dimasukkan ke dalam meta-analisis.

\section{DAFTAR PUSTAKA}

1. Eleni Tsigas. World Preeclampsia Day: Reducing Preventable Deaths From Preeclampsia - Maternal Health Task Force [Internet]. MHTF Blog. 2017. Available from: https://www.mhtf.org/2017/05/22/worldpreeclampsia-day-reducing-preventabledeaths-from-preeclampsia/

2. World Health Organization. Prevention and treatment of pre-eclampsia and eclampsia. 2011.

3. Afifah $\mathrm{T}$, Tejayanti $\mathrm{T}$, Saptarini I, Rizkianti A, Usman Y, Senewe FP, et al. Maternal Death in Indonesia: Follow-up Study of the 2010 Indonesia Population Census. 2016;1-13.

4. Abalos E, Cuesta C, Carroli G, Qureshi Z, Widmer M, Vogel J, et al. Pre-eclampsia, eclampsia and adverse maternal and perinatal outcomes: a secondary analysis of the World Health Organization Multicountry Survey on Maternal and Newborn Health. RCOG. 2014;14-24. DOI: $10.1111 / 1471-0528.12629$.

5. Cripe SM, O'Brien W, Gelaye B, Williams MA. Perinatal outcomes of Southeast Asians with pregnancies complicated by gestational diabetes mellitus or preeclampsia. J Immigr Minor Heal.
2012;14(5):747-53. DOI: 10.1007/s10903011-9537-7.

6. Dawson LM, Parfrey PS, Hefferton D, Dicks EL, Cooper MJ, Young D, et al. Familial risk of preeclampsia in Newfoundland: A population-based study. J Am Soc Nephrol. 2002;13(7):1901-6. DOI:

10.1097/01.ASN.0000017224.24670.82.

7. Valadan M, Tanha FD, Sepahi A. Pregnancy Outcomes in Women of Advanced Age. J Fam Reprod Heal. 2011;5(2):57-62.

8. Bodnar LM, Catov JM, Klebanoff MA, Ness RB, Roberts JM. Prepregnancy body mass index and the occurrence of severe hypertensive disorders of pregnancy. Epidemiology. 2007;18(2):234-9. DOI: 10.1097/01.ede.0000254119.99660.e7.

9. Bodnar LM, Ness RB, Markovic N, Roberts JM. The risk of preeclampsia rises with increasing prepregnancy body mass index. Ann Epidemiol. 2005;15(7):475-82. DOI: 10.1016/j.annepidem.2004.12.008

10. O'Brien TE, Ray JG CW. Maternal Body Mass Index and the Risk of Preeclampsia: A Systematic Overview. Vol. 14, Epidemiology. 2003.

11. Sohlberg S, Stephansson O, Cnattingius S, Wikström AK. Maternal body mass index, height, and risks of preeclampsia. Am J Hypertens [Internet]. 2012;25(1):120-5. Available from: http://dx.doi.org/10.1038/ajh.2011.175/nat ure06264

12. Wang Z, Wang P, Liu H, He X, Zhang J. Maternal adiposity as an independent risk factor for pre-eclampsia: A meta-analysis of prospective cohort studies. Obes Rev. 2013;14(6):508-21. 10.1111/obr.12025.

13. Jeyabalan A. Epidemiology of preeclampsia: impact of obesity. Nutr Rev [Internet]. 2013;71 Suppl 1(0 1):S18-25. DOI: 10.1111/nure.12055.

14. Duckitt K, Harrington D. Risk factors for pre-eclampsia at antenatal booking: Systematic review of controlled studies. $\mathrm{Br}$ Med J. 2005;330(7491):565-7. DOI: 10.1136/bmj.38380.674340.E0.

15. Funai EF, Paltiel OB, Malaspina D, 
Friedlander Y, Deutsch L, Harlap S. Risk factors for pre-eclampsia in nulliparous and parous women: the Jerusalem Perinatal Study. Paediatr Perinat Epidemiol. 2005;19:59-68.

16. Bartsch E, Medcalf KE, Park AL, Ray JG, Risk H. Clinical risk factors for preeclampsia determined in early pregnancy: systematic review and meta-analysis of large cohort studies. BMJ. 2016;1-10. DOI: $10.1136 / \mathrm{bmj} . \mathrm{i} 1753$.

17. Salters-Pedneault KP. The Role of MetaAnalysis in Scientific Studies [Internet]. Very Well Mind. 2018. Available from: https://www.verywellmind.com/definitionof-meta-analysis-425254

18. Nindrea RD. Pengantar Langkah-langkah Praktis Studi Meta Analisis. 1st ed. Hardisman, editor. Yogyakarta: Gosyen Publishing; 2016.

19. Bramham K, Parnell B, Nelson-Piercy C, Seed PT, Poston L, Chappell LC. Chronic hypertension and pregnancy outcomes: systematic review and meta-analysis. BMJ. 2014;348:g2301.

DOI: 10.1136/bmj.g2301.

20. Kurniawan K, Cathleen F, Lieana C, Miranda A V. Maternal Factors Associated with Preeclampsia among Asians: Systematic Review of Large Cohort Studies. J Asian Med Stud Assoc [Internet]. 6(1). Available from: http://jamsa.amsa-

international.org/index.php/main/article/vi ewFile/155/67

21. Lu Y, Chen R, Cai J, Huang Z, Yuan H. The management of hypertension in women planning for pregnancy. Br Med Bull. 2018;128(October):75-84. DOI: 10.1093/bmb/ldy035.

22. Weissgerber TL, Mudd LM. Preeclampsia and Diabetes. Curr Diab Rep. 2015;15(3):579. DOI: 10.1007/s11892015-0579-4.

23. Schneider S, Freerksen N, Röhrig S, Hoeft B, Maul H. Gestational diabetes and preeclampsia-Similar risk factor profiles? Early Hum Dev. 2012;88(3):179-84. DOI: 10.1016/j.earlhumdev.2011.08.004.

24. Carpenter MW, Ramin SM, Casey B, Wapner RJ, Varner MW, Rouse DJ. A Multicenter, Randomized Trial of
Treatment for Mild Gestational Diabetes. N Engl J Med. 2009;361(14):1339-48.

25. Hartling L, Dryden DM, Guthrie A, Muise M, Vandermeer B, Donovan L. Benefits and Harms of Treating Gestational Diabetes Mellitus: A Systematic Review and Meta-analysis for the U.S. Preventive Services Task Force and the National Institutes of Health Office of Medical Applications of Research. Ann Intern Med. 2013;159(2):123-9.

26. Mitchell S, Shaw D. The worldwide epidemic of obesity. Best Pract Res Clin Obstet Gynaecol. 2014;(November):1-11.

27. Chan T, Tung Y, Wang S, Lee C, Lin C, $\mathrm{Lu} P$. Trends in the incidence of preeclampsia and eclampsia in Taiwan between 1998 and 2010. Taiwan J Obstet Gynecol. 2015;54:270-4.

28. Bilano VL, Ota E, Ganchimeg T, Mori R, Souza JP. Risk Factors of PreEclampsia/Eclampsia and Its Adverse Outcomes in Low- and Middle-Income Countries: A WHO Secondary Analysis. PLoS One. 2014;9(3):1-9. DOI:10.1371/journal.pone.0091198.

29. Chiwanga ES, Massenga G, Mlay P, Obure J, Mahande MJ. Maternal outcome in multiple versus singleton pregnancies in Northern Tanzania: A registry-based case control study. Asian Pacific J Reprod. 2014;3(1):46-52. DOI: 10.1016/S23050500(14)60001-4.

30. Conde-agudelo A, Belizan JM. Risk factors for pre-eclampsia in a large cohort of Latin American and Caribbean women. BJOG. 2000;107(1):75-83.

31. Direkvand-moghadam A, Khosravi A, Sayehmiri K. Predictive factors for preeclampsia in pregnant women: a univariate and multivariate logistic regression analysis. Acta Biochim Pol. 2012;59(4):673-7.

32. Bramham K, Briley AL, Seed P, Poston L, Shennan AH, Chappell LC. Adverse maternal and perinatal outcomes in women with previous preeclampsia: a prospective study. Am J Obstet Gynecol [Internet]. 2011;512.e1-512.e9. http://dx.doi.org/10.1016/j.ajog.2011.02.01 4

33. Tessema GA, Tekeste A, Ayele TA. 
Preeclampsia and associated factors among pregnant women attending antenatal care in Dessie referral hospital, Northeast Ethiopia: a hospital-based study. BMC Pregnancy Childbirth. 2015;15:73. DOI: 10.1186/s12884-015-0502-7.

34. Shamsi U, Hatcher J, Shamsi A, Zuberi N, Qadri Z, Saleem S. A multicentre matched case control study of risk factors for Preeclampsia in healthy women in Pakistan. BMC Womens Health. 2010;10:14. Downloaded from: http://www.biomedcentral.com/14726874/10/14.

35. Luealon P, Phupong V. Risk Factors of Preeclampsia in Thai Women. J Med Assoc Thai. 2010;93(6):661-6. http://www.thaiscience.info/journals/Articl e/JMAT/10657975.pdf.

36. Khader Y, Jibreal M, Burgan S, Amarin Z. Risk Indicators of Pre-Eclampsia in North Jordan: Is Dental Caries Involved? Gynecol Obstet Invest. 2007;63:181-7. DOI: 10.1159/000097633.

37. Kumar G, Unnikrishnan B, Nagaraj K, Jayaram S. Determinants of Pre-eclampsia: A Case-control Study in a District Hospital in South India. Indian J Community Med. 2010;35(4):502-5.

38. Fang R, Dawson A, Lohsoonthorn V, Williams MA. Risk Factors of Early and Late Onset Preeclampsia among Thai Women. Asian Biomed (Res Rev News). 2009;3(5):477-86.

https://www.ncbi.nlm.nih.gov/pmc/articles /PMC3101572/pdf/nihms251109.pdf.

39. Al-Tairi ANQ, Isa Z, Ghazi HF. Risk factors of preeclampsia: a case control study among mothers in Sana'a, Yemen. J Public Heal. 2017;25:573-80. DOI: 10.1007/s10389-017-0825-0.

40. Grum T, Seifu A, Abay M, Angesom T, Tsegay L. Determinants of preeclampsia/Eclampsia among women attending delivery Services in Selected Public Hospitals of Addis Ababa, Ethiopia: a case control study. BMC Pregnancy Childbirth. 2017;17:307. DOI: 10.1186/s12884-017-1507-1.

41. Anorlu RI, Iwuala NC, Odum CU. Risk factors for pre-eclampsia in Lagos, Nigeria. Aust New Zeal J Obstet
Gynaecol. 2005;45:278-82.

42. Kiondo P, Wamuyu-maina G, Bimenya GS, Tumwesigye NM, Wandabwa J. Risk factors for pre-eclampsia in Mulago Hospital, Kampala, Uganda. Trop Med Int Heal. 2012;17(4):480-7. DOI:10.1111/j.1365-3156.2011.02926.x.

43. Grum T, Hintsa S, Hagos G. Dietary factors associated with preeclampsia or eclampsia among women in delivery care services in Addis Ababa, Ethiopia: a case control study. BMC Res Notes. 2018;11:683. https://doi.org/10.1186/s13104-018-37938.

44. Mohammed E, Agero G, Ali E. Preeclampsia Risk Factors among Pregnant Women Attending in Four Public Health Facilities of Addis Ababa City. Ethiop J Reprod Heal. 2017;9(1). https://doi.org/10.1186/s13104-018-37938.

45. Wandabwa J, Doyle $\mathrm{P}$, Kiondo $\mathrm{P}$, Campbell O, Maconichie N, Welishe G. Risk Factors for Severe Pre-eclampsia and Eclampsia in Mulago Hospital, Kampala, Uganda. East Afr Med J. 2010;87(10):415-24.

https://www.ajol.info/index.php/eamj/articl e/download/76267/66734.

46. Endeshaw M, Abebe F, Bedimo M, Asrat A, Gebeyehu A, Keno A. Family history of hypertension increases risk of preeclampsia in pregnant women: a casecontrol study. Universa Med. 2016;35(3):181-91. DOI: 10.18051/UnivMed.2016.v35.181-191.

47. Guerrier G, Oluyide B, Keramarou M, Grais RF. Factors associated with severe preeclampsia and eclampsia in Jahun, Nigeria. Int $\mathbf{J}$ Womens Health. 2013;5:509-13. Downloaded from: https://doi.org/10.2147/IJWH.S47056.

48. Shao Y, Qiu J, Huang H, Mao B, Dai W, $\mathrm{He} \mathrm{X}$. Pre-pregnancy BMI, gestational weight gain and risk of preeclampsia: a birth cohort study in Lanzhou, China. BMC Pregnancy Childbirth. 2017;17:400. DOI: $10.1186 / \mathrm{s} 12884-017-1567-2$.

49. You S, Cheng P, Chung T, Kuo C, Wu H, Chu P. Population-based trends and risk factors of early- and late-onset 
preeclampsia in Taiwan 2001-2014. BMC Pregnancy Childbirth. 2018;18:199. Downloaded from: https://doi.org/10.1186/s12884-018-18457.

50. Lee C, Hsieh T, Chiu T, Chen K, Lo L, Hung TU. Risk factors for pre-eclampsia in an Asian population. Int $\mathbf{J}$ Gynecol Obstet. 2000;70:327-33.

51. Li X, Tan H, Huang $X$, Zhou $\mathrm{S}, \mathrm{Hu} \mathrm{S}$, Wang X, et al. Similarities and differences between the risk factors for gestational hypertension and preeclampsia: A population based cohort study in south China. Pregnancy Hypertens An Int J Women's Cardiovasc Heal. 2015; Downloaded http://dx.doi.org/10.1016/j.preghy.2015.11. 004.

52. Mrema D, Lie RT, Østbye T, Mahande MJ, Daltveit AK. The association between pre pregnancy body mass index and risk of preeclampsia: a registry based study from Tanzania. BMC Pregnancy Childbirth. 2018;18:56.

https://doi.org/10.1186/s12884-018-16873.

53. Musa J, Mohammed C, Ocheke A, Kahansim M, Pam V, Daru P, et al. Incidence and risk factors for preeclampsia in Jos Nigeria. Afr Health Sci. 2018;18(3):584-95.

DOI: https://dx.doi.org/10.4314/ahs.v18i3.16. 